\title{
STUDIES ON CALCIUM CONTENT IN SEA WATER. I. CHELATOMETRIC DETERMINATION OF CALCIUM IN SEA WATER
}

\author{
(Received for publication in 1959)
}

\author{
KenJi Kato * \\ Faculty of Fisheries, Hokkaido University - Japan \\ Oceanographic Institute, University of São Paulo - Brazil
}

\begin{abstract}
SYNOPSIS
The chelatometry - volumetric titration whith a chelate compound such as EDTA-2Na (disodium ethylenediaminetetracetate) - was applied to the determination of calcium in sea water. Sea water contains in general, approximately three times more magnesium than calcium. It is true that the chelatometry has presently given the possibility* of selective analysis of calcium in the coexistence of magnesium, but an abundant amount of coexisting magnesium, as in the case of sea water, is likely to cause an unfavorable negative-error of the titre in titrating calcium with EDTA using murexide indicator in a strongly alkaline medium.

The author firstly examined how the negative error of the titre was affected by the probable conditions of the analysis; i.e., the quantity of coexisting magnenium, the hydrogen-ion concentration of the medium, and the addition of a masking reagent, as sucrose or sodium carbonate.

These chemical examinations about the analytical conditions led to a procedure of analysis, by means of which it is possible to determine calcium in sea water easily, in a few minutes, with fairly high precision. As this method is very simple and gives an accuracy of $\pm 0.4 \%$ using only $10 \mathrm{ml}$ of the water sample, it is recommended as a procedure to determine calcium in oceanographical observations aboard, in which a lot of water samples have to be analysed in a comparatively short period of time.
\end{abstract}

\section{INTRODUCTION}

Calcium in sea water is of great interest for oceanography and marine biology. A good deal of investigation has therefore been dedicated to problems of calcium in the water. The calcium oxalate method has usually been employed for separating calcium from other elements in the sample. It is known that the quantitative precipitation of calcium as its oxalate is not always feasable when a lot of magnesium is present in the sample. In sea water, the magnesium content is three times that of calcium (Mg: $1272 \mathrm{mg} / \mathrm{kg}, \mathrm{Ca}: 400 \mathrm{mg} / \mathrm{kg}$, on average, in sea water of $19 \%$ chlorinity, according to SVERDRUP et al., 1942). Naturally, in the case of sea water, there occurs a probable risk of magnesium contamination during the precipitation of calcium oxalate. To obtain the complete quantitative precipitation of calcium, Thомpson and WRIGHT (1930) recommended triple precipitations at least, while KIRK and MoвErg (1933) obtained a favorable result

\footnotetext{
* At present in the Faculty of Fisheries, Prefectural University of Mie, Tsu, Japan.
}

after only two precipitations. GRIPENBERG (1937a) called attention to the fact that the amount of magnesium coprecipitated with calcium oxalate decreases with the depression of $\mathrm{pH}$ in the medium containing sodium acetate. More or less, these quantitative separating processes of calcium by means of precipitation need complicated and tedious treatments involving repeated precipitations, so that the precipitation might be completed.

Wattenberg and Timmermann (1936) examined the correlation between the quantity of calcium and the equilibrium of the carbon dioxide system occurring in sea water. They placed emphasis on the fact that changes in the alkalinity and calcium were of common origin namely, precipitation or solution of calcium carbonate. Actually, W BERG (1933) determined the alkalinity and chlorinity in the 'Meteor' Expedition as related to the carbon dioxide system in sea water, without the determination of calcium. In this case, he employed the ratio of alkalinity to chlorinity ("specific alkalinity") as an index of the deviation of calcium content in the 
sample. Further, even in the Swedish Deep-Sea Expedition, 1947-48, the determination of calcium in their water samples was not carried out because of the troublesome procedures mentioned above in the practical analysis of calcium.

The prediction of calcium content from its corresponding specific alkalinity depends upon the supposition that calcium in sea water exists in the form of carbonate and that its distribution is absolutely controlled by the chemical equilibrium of the carbon dioxide system of the sea water. But, the above supposition seems sometimes doubtful. WATTENBERG and Trmmermann (1936) estimated the apparent solubility product, $\mathrm{K}^{\prime} \mathrm{CaCO}_{3}$, in sea water as $0.62 \times$ $\times 10^{-6}$, whereas Revelle and Fleming (1934) estimated the same as $3.2 \times 10^{-6}$. Related to this discrepancy, WATTENBERG imagined the partial existence of calcium in the forms of suspension and complex compounds. With respect to the present problem Sverdrup et al. (1942) concluded: "It may be that the empirically determined values of $\mathrm{K}^{\prime} \mathrm{CaCO}_{3}$ are not applicable to sea water because of lack of equilibrium or faulty experimental technique. Further studies must be made before these points can be decided."

Gripenberg (1937b) observed from the water samples of the Baltic Sea that excess base values were found to fit less to linear relation than the calcium values, and that analyses of one and the same water sample differed, in many cases, by several units in the second decimal. Thus, she imagined the existence of unknown substances, probably in part volatile, which notably influenced the excess base value in Baltic waters.

Accordingly, it is reasonable to search for a simple and direct method with high precision required for determining calcium in sea water. A remarkable progress of instrumental analysis is the flame spectrophotometric determination of calcium in sea water of marine organisms (CHow \& THомpson, 1955). This instrumental method seems not to be always applicable in routine work of oceano- graphy. The author has therefore applied chelatometry - namely, volumetric titration with a chelate reagent for determining calcium in sea water.

In the present study di-sodium ethylenediaminetetracetate (EDTA - 2Na) was used, as the chelate reagent:

$$
\underset{\mathrm{NaOOC}-\mathrm{H}_{2} \mathrm{C}}{\mathrm{HOOC}-\mathrm{H}_{2} \mathrm{C}}>\mathrm{N}-\mathrm{CH}_{2}-\mathrm{CH}_{2}-\mathrm{N}<\underset{\mathrm{CH}_{2}-\mathrm{COONa}}{\mathrm{CH}_{2} \mathrm{COOH}} \text { (EDTA-2Na) }
$$

Chelatometric titration (Schwarzenbach 1957; Martell \& Calvin 1951) gives many splendid achievements on selective determination of calcium when there is the simultaneous presence of magnesium in the sample. But, few papers have been published on the determination of calcium in sea water (DE SousA, 1954). In this paper the author will therefore examine first the analytical conditions of the practise of calcium determination in sea water, so as to achieve his own method of analysis for oceanographical use.

\section{EXPERIMENTS}

\section{Effects of magnesium in chelatometric titration of calcium}

In sea water, magnesium content amounts to about three times more than does the calcium content. A preliminary experiment was done to examine the influences of the coexisting magnesium upon the titre of EDTA in determining calcium. An aliquote portion of $\mathrm{MgCl}_{2}$ solution (1.3 mg-Mg/ml) was added to $10 \mathrm{ml}$ of $\mathrm{CaCl}_{2}$ solution containing $0.40 \mathrm{mg} / \mathrm{ml}$ of calcium. After the solution was filled up to $50 \mathrm{ml}$ with distilled water, $5 \mathrm{ml}$ of $\mathrm{N}$. $\mathrm{NaOh}$ solution was added to the solution, by which the medium was prepared to be strongly alkaline (over $\mathrm{pH}$ 12). After stirring well for five minutes, the solution was titrated with 0.01 M EDTA solution, using Murexide as an indicator, to the color change from red to violet. These results are given in Table I.

TABLE I - Influence of $\mathrm{Mg}$ upon determining $\mathrm{Ca}$ with EDTA (each sample contains $4.00 \mathrm{mg}$ of $\mathrm{Ca}$ )

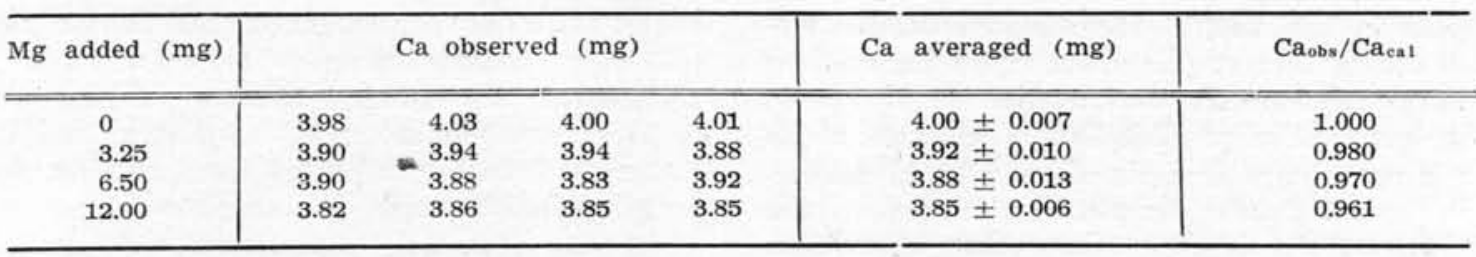

Table I shows that the observed values of calcium are likely to come a few percent lower under the influence of magnesium since some calcium is carried down by the precipitation of magnesium hydroxide.

\section{Influence of $\mathrm{pH}$ of the medium upon the de- termination of $\mathrm{Ca}$ in sea water}

Firstly, a series of water samples were prepared in which the same ratio between calcium and mag. nesium was maintained as in sea water. Namely, these samples contained respectively $0.40 \mathrm{mg} / \mathrm{ml}$ of $\mathrm{Ca}$ and $1.20 \mathrm{mg} / \mathrm{ml}$ of $\mathrm{Mg}$, but were respectively different in $\mathrm{pH}$ values. These samples were titrated with EDTA solution in the same manner as mentioned above, their results being shown in Table II.

The checking of the influence of the $\mathrm{pH}$ value as shown in Table II makes possible to render the magnesium error almost negligible, if the $\mathrm{pH}$ value of the medium is made up to $\mathrm{pH} 12$. The lower values of the $\mathrm{pH}$ lead to rather high titres, while the higher $\mathrm{pH}$ is apt to cause a negative error of the titre. 
TABLE II - Influence of $\mathrm{pH}$ medium upon selective determination of $\mathrm{Ca}$ (each sample contains respectively $4.00 \mathrm{mg} \mathrm{Ca}$ and $12.00 \mathrm{Mg}$ )

\begin{tabular}{c|ccc|c}
\hline $\mathrm{pH}$ & Ca & observed $(\mathrm{mg})$ & Ca averaged $(\mathrm{mg})$ \\
\hline \hline & & & & \\
11.0 & 4.66 & 4.78 & 4.68 & $4.71 \pm 0.025$ \\
11.7 & 4.37 & 4.28 & 4.33 & $4.33 \pm 0.018$ \\
12.0 & 4.02 & 3.98 & 3.99 & $4.00 \pm 0.008$ \\
13.0 & 3.85 & 3.84 & 3.83 & $3.84 \pm 0.004$ \\
\hline
\end{tabular}

3. Effects of sodium carbonate and sucrose upon the negative error in titrating calcium with EDT A reagent

So as to prevent the negative error mentioned above from occurring some of the following advices on the pretreatment are made: one, to precipitate calcium prior to titration, in the form of carbonate which will easily be soluble on addition of EDTA solution; the other, to use such a weak chelate reagent as mannitol or sucrose to protect the calcium ion from fixation on the precipitate of magnesium hydroxide.

Here, following the above recommendations, the author made some attempts to prevent the occurrence of negative error. An aliquote portion of $20 \%$ sugar solution and/or $0.2 \mathrm{M}$ sodium carbonate solution was added previously into $50 \mathrm{ml}$ of the sample solution. Next, the treated sample solution was titrated, after being made alkaline, with EDTA reagent in the presence of the indicator.

TABLE III - Effects of $\mathrm{Na}_{2} \mathrm{CO}_{3}$ and sucrose upon negative error in titrating Ca with EDTA (each $50 \mathrm{ml}$ of the sample used contains $4.00 \mathrm{mg} \mathrm{Ca}$ and $12.00 \mathrm{mg} \mathrm{Mg}$ )

\begin{tabular}{|c|c|c|c|c|c|c|c|c|c|}
\hline & $\begin{array}{l}20 \% \text { sugar } \\
\text { solution }(\mathrm{ml})\end{array}$ & $\begin{array}{c}0.2 \mathrm{M} \mathrm{N}_{2} \mathrm{CO}_{3} \\
(\mathrm{ml})\end{array}$ & $\begin{array}{l}\mathrm{N}-\mathrm{NaOH} \\
(\mathrm{ml})\end{array}$ & \multicolumn{4}{|c|}{$\begin{array}{c}\text { Ca observed } \\
(\mathrm{mg})\end{array}$} & $\mathrm{Ca}$ & $\begin{array}{l}\text { averaged } \\
(\mathrm{mg})\end{array}$ \\
\hline (1) & 0 & 0 & 5 & 3.85 & 3.86 & 3.84 & 3.83 & & 3.84 \\
\hline (2) & 0 & 1 & 5 & 3.87 & 3.89 & 3.88 & 3.86 & & 3.88 \\
\hline (3) & 1 & 0 & 5 & 3.84 & 3.82 & 3.85 & 3.84 & & 3.84 \\
\hline (4) & 1 & 1 & 5 & 3.89 & 3.91 & 3.91 & 3.86 & & 3.89 \\
\hline (5) & 2 & 1 & 5 & 3.93 & 3.89 & 3.88 & 3.87 & & 3.89 \\
\hline (6) & 1 & 1 & 4 & 3.89 & 3.89 & 3.85 & 3.89 & & 3.88 \\
\hline (7) & 1 & 1 & 3 & 3.93 & 3.89 & 3.89 & 3.89 & & 3.90 \\
\hline
\end{tabular}

Table III shows that addition of the solutions of carbonate or sugar are not so effetive for the purpose of preventing the negative error of the titre in a strongly alkaline solution. Consequently, it is important to prepare the medium so as to be exactly $\mathrm{pH} 12$ for obtaining a correct response to the calcium content. These masking reagents used have, of course, been preliminarily treated to free them from calcium contamination. For example, the sugar solution must be passed through a column of cationexchange resin such as Amberlite IR-120.

\section{METHOD OF DETERMINING CALCIUM IN SEA WATER}

\section{Reagents}

1) $0.01 \mathrm{M}$ EDTA-2Na Solution: EDTA-2Na (disodium ethylenediaminetetracetate), C.A., 3.9 g, is dissolved in 1 liter of redistilled water. The solution is to be stored in a Pyrex glass bottle which has been well treated with steam. Polyethylene is also very suitable as a storage vessel. In the course of time ordinary glass yields an appreciable amount of calcium to solutions of EDTA.

2) Murexide Indicator: $0.4 \mathrm{~g}$ of murexide, C.A., is mixed with $100 \mathrm{~g}$ of dried $\mathrm{NaCl}, \mathrm{C} . \mathrm{A}$. (or
$\mathrm{KCl}$ ), and is well pulverized in an agate mortar. The pulverized indicator mixture should be stored in a brown-colored vial avoiding the exposure to solar radiation and unfavorable moisture.

3) $1 \mathrm{~N} \mathrm{NaOH}$ : Dissolve $40 \mathrm{~g}$ of $\mathrm{NaOH}$, C.A., in redistilled water and dilute to 1 liter.

4) $0.01 \mathrm{CaCl}_{2}$ Solution: Weigh exactly $1.001 \mathrm{~g}$ of $\mathrm{CaCO}_{3}$ dried at $110^{\circ} \mathrm{C}$, dissolve it in a little portion of $\mathrm{HCl}$ and dilute to 1 liter with redistilled water.

5) $\mathrm{MgCl}_{2}$ Solution: Dissolve $5.884 \mathrm{~g}$ of $\mathrm{MgCl}_{2} \cdot 6 \mathrm{H}_{2} \mathrm{O}$ in redistilled water and dilute to 1 liter. This solution contains $1.2 \mathrm{mg} / \mathrm{ml}$ of magnesium.

\section{Calibration of EDTA solution and actual procedure of determination.}

Take $10 \mathrm{ml}$ of a standard solution of calcium (4) with a pipette into an Erlenmayer flask, $250 \mathrm{ml}$ in capacity. Add $10 \mathrm{ml}$ of $\mathrm{MgCl}_{2}$ solution (5) and $30 \mathrm{ml}$ of distilled water. This solution contains 4.0 $\mathrm{mg}$ of $\mathrm{Ca}$ and $1.2 \mathrm{mg}$ of $\mathrm{Mg}$, and gives approximately the same ratio of $\mathrm{Ca} / \mathrm{Mg}$ as that of sea water. To the above solution add $\mathrm{N}-\mathrm{NaOH}$ (3) to adjust the medium to $\mathrm{pH}$ 12. After stirring for five minutes, titrate the $\mathrm{pH}$-adjusted solution with $0.01 \mathrm{M}$ EDTA 
solution (1) until the color changes from red to violet. One milliliter of EDTA solution is theoretically equivalent to $0.4008 \mathrm{mg}$ of calcium. The calibration of calcium as described above will certainly contribute to minimize the negative error of titre in the actual determination of calcium in the sea water sample.

In the actual determination of calcium in the sea water sample, $10 \mathrm{ml}$ of the sample is taken with a pipette and diluted with $40 \mathrm{ml}$ of distilled water. The titration process is quite similar to the calibration procedure.

The author recommends the use of a standing fluorescent lamp for illuminating the titration apparatus. The lamp is very useful in observing the delicate change of color from red to violet at the end of titration. Thus, it is possible to determine the calcium in sea water easily, in only several minutes time, with a precision within $0.4 \%$ of standard error.

The present method of determining calcium with EDTA reagent was employed during the calcium analysis of the water samples from the South Atlantic off Brazil and from the Cananéia Lagoon and its adjacent areas in the São Paulo State. The results of these studies are described in other papers. The chelatometry can also be used of course to simultaneous determinations of magnesium and calcium in sea water by means of an almost similar procedure; namely, at $\mathrm{pH} 10$, using Eriochrome Black $\mathrm{T}$ as an indicator. Consequently, the response of magnesium is given by the difference between the two titres at the mediums of $\mathrm{pH} 10$ and 12 . These titrations should be done separately for the same sample.

\section{ACKNOWLEDGEMENTS}

The author is much indebted to Prof. W. BesNARD, Director of the Oceanographic Institute, University of São Paulo, for his untiring encouragement and instructive suggestions in the present investigation. Thanks are also due to Messrs. I. EMILsson and M. FURUYA for furnishing the author with facilities for this work.

The present investigation was rendered possible through the support given by a fellowship grant from the National Research Council, Brazil, to which the author expresses his sincere thanks.

\section{R ES U M O}

Empregamos a complexometria - titulação volumétrica com um composto complexométrico como - EDTA-2Na (disodium ethylenediaminetetracetate) para a determinação do cálcio na água do mar. A complexometria nos dá, atualmente, a possibilidade de fazer uma análise seletiva do cálcio, na presença do magnésio; mas uma quantidade grande de magnésio, como no caso da água do mar, irá provàvelmente, ocasionar um êrro negativo desfavorável no título, quando o cálcio fôr titulado com EDTA, empregando-se o indicador murexida num meio altamente alcalino, com $\mathrm{pH}$ acima de 12 .

$\mathrm{O}$ autor procurou, primeiramente, saber de quanto seria afetado o êrro negativo do título, por possí- veis condições de análise, tais como a quantidade presente de magnésio, a concentração hidrogênio-iônica do meio e a adição de alguns reagentes mascarantes recomendáveis, isto é, sucrose e carbonato de sódio.

Êsses estudos químicos sôbre as condições analíticas levaram a um nôvo processo de análise, por meio do qual se poderá determinar, fàcilmente, o cálcio na água do mar, em poucos minutos, e com uma precisão razoàvelmente alta. Como êsse método é muito simples e dá uma boa precisão $( \pm 0,4 \%$ de êrro padrão), com uma amostra de sòmente $10 \mathrm{ml}$ de água, seria muito interessante que a determinação do cálcio fôsse uma das análises de rotina nos estudos oceanográficos, quando há necessidade de se analisar grande número de amostras de água em um espaço de tempo relativamente curto.

\section{R EFERENCES}

Chow, T. J. \& Thompson, T. G.

1955. Flame-photometric determination of calcium in sea water and marine organims. Analyt. Chem., vol. 27, p. 910.

De Souza, A.

1954. La détermination rapide du calcium et magnesium dans l'eau de mer. Analytica chim. Acta, vol. 11, p. 221.

GRIPENBERG, S.

1937a. A simplified method for the determination of calcium in sea water. J. Cons. perm. int. Explor. Mer, vol. 12, n. ${ }^{\circ} 3$, p. 284-292, figs. tabs.

1937b. The calcium content of Baltic water. Ibid., vol. 12 , n. ${ }^{\circ} 3$, p. $293-304$, figs. tabs.

KIRK, P. L. \& MoberG, E. G.

1933. Microdetermination of calcium in sea water. Ind. Engng Chem. analyt. End. vol. 5 , p. 95 .

Martell, A. \& Galvin, M.

1951. Chemistry of the metal chelate compounds. New York, Prentice-Hall.

Revelle, R. \& Fleming, R. H.

1934. The solubility product constant of calcium carbonate in sea water. Fifth $\mathrm{Pa}$ cific Sci. Congr., Canada, 1933. (Cf. SverdRup et al., 1942).

SchWARZENBACH, G.

1957. Complexometric titrations. Translated by I. Irving. London, Methuen \& Co. $132 \mathrm{p}$.

Sverdrup, H. U., Johnson, M. W. \& Fleming, R. H. 1942. The oceans, their physics, chemistry and biology. New York, Prentice-Hall, 1087 p. graf. tabs. maps.

Thompson, T. G. \& Wright, C. C.

1930. Ionic ratios of the waters of the North Pacific Ocean. J. Amer. chem. Soc., vol. 52 , p. 915 .

WATTENBERG, $\mathrm{H}$.

1933. Kalziumkarbonat- und Kohlensäuregehalt des Meerwassers. Wiss. Ergebn. dt. atlant. Exped. 'Meteor', vol. 8, 333 p.

Wattenberg, H. \& TimmermanN, E.

1936. Ueber die Sättigung des Seewassers an $\mathrm{CACO}_{3}$. Annln Hydrogr. Berl., p. 23. 